\title{
Inoculum potential of Fusarium verticillioides and performance of maize seeds
}

\author{
José da Cruz Machadoํㅜ, Andréia Quixabeira Machado², Edson Ampélio Pozza ${ }^{1}$, Cibele Ferreira Machado ${ }^{3}$ \\ \& Willian Luis Antonio Zancan ${ }^{1}$
}

\begin{abstract}
${ }^{1}$ Departamento de Fitopatologia, Universidade Federal de Lavras, Cx. Postal 3037, 37200-000, Lavras, MG, Brazil; ${ }^{2}$ Laboratório de Fitopatologia, Universidade de Várzea Grande, 78118-000, Várzea Grande, MT, Brazil; ${ }^{3}$ Biotechnology Laboratory, Dow AgroSciences, 14140-000, Cravinhos, SP, Brazil
\end{abstract}

Author for correspondence: José da Cruz Machado, e-mail: machado@dfp.ufla.br

\begin{abstract}
This work was conducted to evaluate the effect of Fusarium verticillioides on the early stage development of maize seedling/plants, considering different inoculum potentials of this fungus in seeds, under controlled conditions. To obtain seeds with different inoculum potentials of that fungus, the osmo-priming technique as referred to in literature was used. By this technique, the non-germinated seeds of the same lot, exhibiting typical structures of F. verticillioides, were grouped into five categories according to a grading system that was established based on the visible area of the seeds covered by the fungal structures. Seeds of each category were sowed in soil substrate and plants were grown under controlled conditions, $25^{\circ} \mathrm{C}$ and $16 \mathrm{~h} \mathrm{light/day,} \mathrm{for} 25$ days. All variables used, plant population (stands), speed of seedling emergence, and height/weight of emerged plants, were negatively affected by the increase of the inoculum intensity of the fungus initially present in the seeds. The regression equation showed high values of correlation coefficient $(>0.85)$ for all variables, except for plant height which presented correlation coefficient of 0.77 . The most severe effect of the fungus in this study occurred on the root system of the emerged plants as determined by the highest inoculum intensity of the pathogen on the planted seeds.
\end{abstract}

Key words: Fusarium moniliforme, Zea mays, mannitol, osmo-priming technique.

\section{INTRODUCTION}

The interaction between Fusarium verticillioides (syn. F. moniliforme) and maize seeds is an old and conflicting matter under discussion by plant pathologists and seed producers. To some researchers, that fungus is a weak pathogen of maize causing little damage to seed germination, and to others, it is responsible for significant losses to farmers by causing stalk and root rot in the field and ear rot after harvest (De Leon, 1984; Fernandes and Oliveira, 2000; Yates et al., 2005).

That species of Fusarium is also reported as part of the fungal complex producing toxins, such as fumonisin, when associated with kernels and that becomes a big concern for the quality control of maize food stuff used by humans and animals (Neergaard, 1979; Singh et al., 1991; Lazzari, 1993; Rheeder et al., 2002; Dall'Asta et al., 2012). According to literature, F. verticillioides is commonly found in association with seeds and kernels of maize at variable levels, mostly at high incidence (Neergaard, 1979; Richardson, 1979; Wilke et al., 2007). Under the Brazilian conditions, F. verticillioides is associated mostly with pre-emergence seed rot and seedling damping-off in maize (Fernandes and Oliveira, 2000), being detected in commercial seed lots at high incidences. Results of seed health analysis conducted in the Seed Pathology Laboratory of the Federal University of Lavras over the last ten years reveal that such Fusarium species is quite frequent and occurs at high percentages in certified seed samples of maize.

According to reports in literature Fusarium veriticillitioides is able to reduce seed germination of maize as well as vigor at variable levels, but no precise data are provided to support that effect. According to Machado (2000) different variables can be used to evaluate the effect of a pathogen on seed germination and vigor of which inoculum potential is quite important in addition to incidence of the organism in the seed lot. The conflicting information found in literature about the relationship between Fusarium veriticillioides and maize seeds may be the result of the use of seed lots presenting different incidence levels of the organism, without any indication on inoculum potential in the seeds. In the present work the objective was to evaluate the effect of Fusarium verticillioides on maize seed quality by using the osmo-priming technique which is the only mean to provide different inoculum potentials of a pathogen from a same seed lot as demonstrated for other pathosystems (Machado et al, 2012).

\section{MATERIAL AND METHODS}

\section{Seed origin and selection}

The selection of the seed lot was made basing on the results of seed health and standard germination tests 
(Neergaard, 1979; ISTA, 1996; Machado et al., 2002) run at the Seed Pathology Laboratory of the Federal University of Lavras. From those analysis, seeds of maize, Hybrid $30 \mathrm{~F} 80$, presenting a germination percentage of $97 \%$ and an incidence of $60.5 \%$ of Fusarium verticillioides, were selected. That seed lot presented also Penicillium oxalicum at incidence of $1 \%$.

\section{Procedure to obtain seeds with different inoculum potentials of Fusarium verticillioides}

Following previous reports (Carvalho, 1999; Machado et al., 2012), the selected seeds naturally contaminated with $F$. verticillioides were submitted to standard blotter method modified by the addition of mannitol to the water used to moisten the filter paper pad substrate. The concentration of mannitol (water restrictor) was based on the software SPPM (Michel and Radcliffe, 1995) so as to provide a solution with osmotic potential of $-1.2 \mathrm{MPa}$.

Seeds were evenly distributed on wet blotters in 15 cm-diameter Petri dishes (30 seeds/dish) and kept in BOD incubator at $20 \pm 2^{\circ} \mathrm{C}$ with photoperiod of 12 hours for 6 days. One hundred dishes were used in that phase meaning three thousand seeds plated out.

Non-germinated seeds with typical frutifications of $F$. verticillioides were grouped into five categories: 1 - seeds with no visible fungal mycelium; 2- mycelium covering up to $25 \%$ of the seed surface; 3 - mycelium on 25 to $50 \%$ of the seed;
4- mycelium covering $50-75 \%$ of the seeds; and 5- mycelium present on over $75 \%$ of the seed surface (Figure 1).

\section{Seed sowing and seedling/plant performance evaluation}

One hundred seeds of each category (inoculum intensity) were sown in plastic trays $(45 \times 38 \times 12 \mathrm{~cm})$ containing soil substrate composed by an autoclaved mixture of soil, sand, and manure in the proportion of 1:1:1. Twenty five seeds were evenly sowed per tray, all trays being kept in a growth room at $25^{\circ} \mathrm{C}$ under $16 \mathrm{~h}$ light $/ 8 \mathrm{~h}$ dark for 25 days, with daily controlled irrigation during the experiment period.

The effects of $F$. verticillioides on the performance of maize seeds were evaluated by making records of the following variables: 1- plant population (stands) at 15 and 25 days after sowing; 2- speed of emergence index according to Maguire (1962); 3- plant height on the 15th day, and fresh and dry weights of shoot and root systems of plants on the 25th day after sowing. Dry weights were determined by using a circulating air incubator at $40^{\circ} \mathrm{C}$ for $72 \mathrm{~h}$.

\section{Experimental design and statistical analysis}

The experiment was set up in a completely randomized design with four replicates, each replicate represented by one seeding tray with 25 seeds. Data were submitted to regression analysis to determine correlations

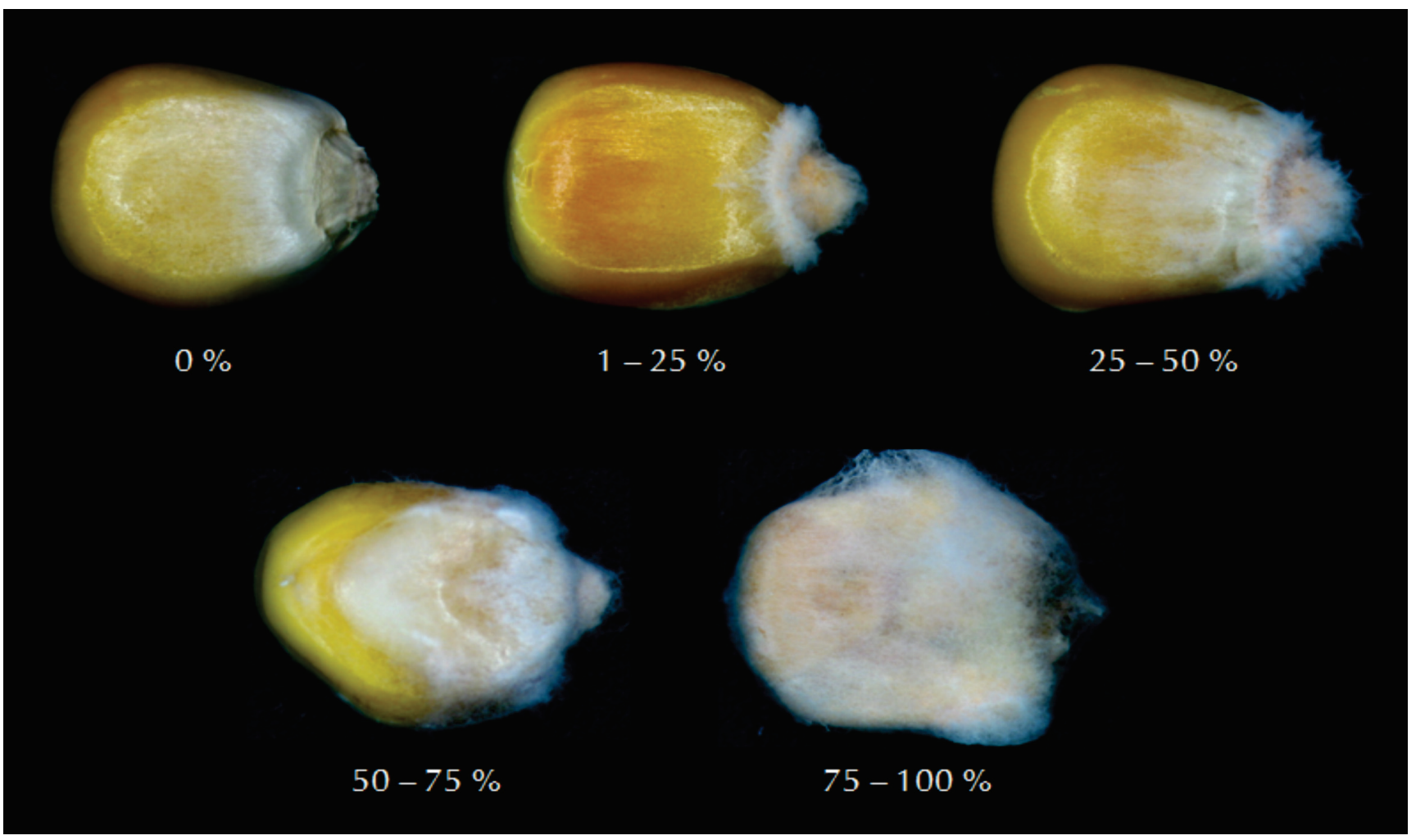

FIGURE 1 - Grading scale established for Fusarium verticillioides inoculum potential, ranging from one to five, based on the percentage area of maize seeds covered by the fungal structures as seen in stereo-microscope. 
between classes of inoculum intensity (potential) and all variables considered in this trial.

\section{RESULTS}

The results shown in Figures 2 and 3 provide evidence that Fusarium verticillioides may be quite damaging to maize at the initial stage of the crop development depending on its inoculum potential present in the seeds. Plant population (stands) declined gradually in the proportion of the inoculum potential evaluated at 15 and 25 days after sowing (Figure 2);
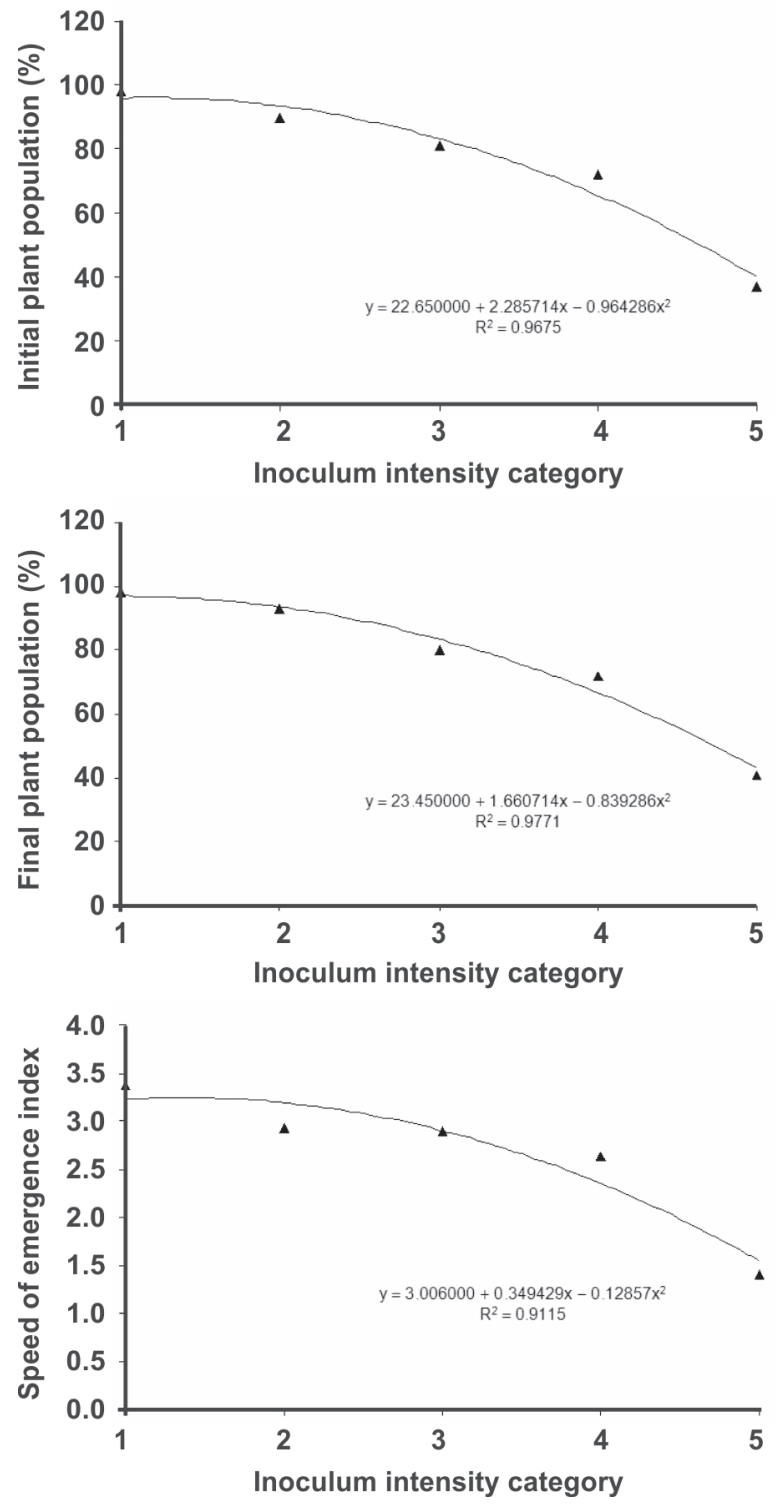

FIGURE 2 - Correlation between plant stands and speed of emergence index and inoculum intensity (potential) of Fusarium verticillioides in maize seeds. Inoculum intensity categories as defined by the percentage area of the seeds covered by the fungal structures. a reduction of about $60 \%$ in such variable occurred when inoculum intensity of the fungus was higher than $75 \%$ according to the grading system used in this work. For both features initial and final stands, the correlation coefficients $\left(\mathrm{R}^{2}\right)$ were high, then explaining the exclusive effect of that pathogen on seed and seedling performance of maize under the circumstances of this experiment.

For the other variables like emergence speed index, and plant heights and weights (Figures 2 and 3), the effects
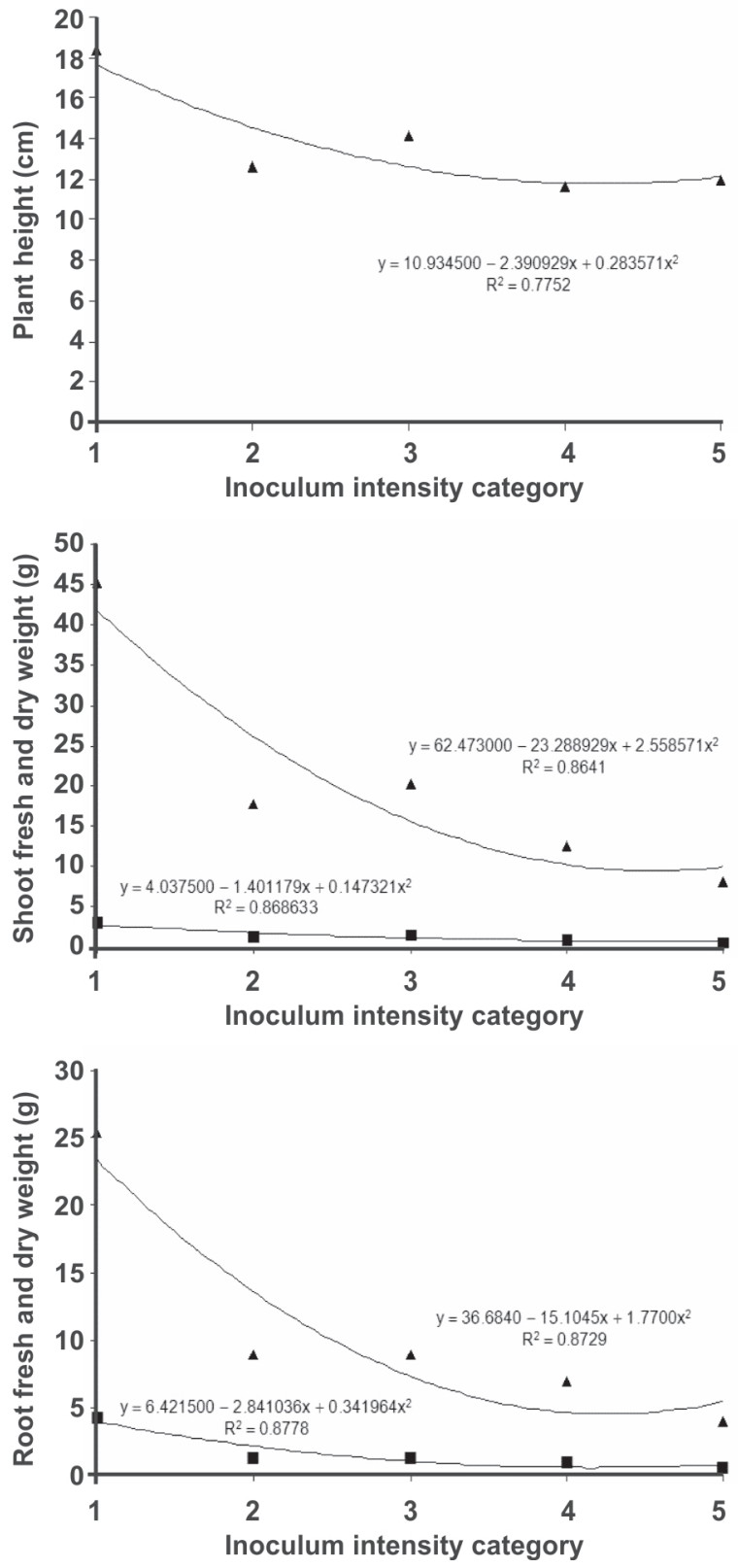

FIGURE 3 - Correlation between plant height and fresh $(\boldsymbol{\Delta})$ and dry (a) weights of shoot and root systems and inoculum intensity (potential) of Fusarium verticillioides in maize seeds. Inoculum intensity categories as defined by the percentage area of the seeds covered by the fungal structures. 
of $F$. verticillioides on maize performance were similar as recorded for plant stands, with little variation between averages. Regarding the effects of that fungus on the root system, it was clear that the damages were also quite high with the increased inoculum potential in the seeds. The dry weight in this case was reduced to almost nil when seeds, used for planting, were covered by the fungal mycelium at proportions higher than $75 \%$ (Figure 3 ). It is also timely to register that, in any case, necrotic symptoms on the roots caused by $F$. verticillioides were seen. Except for the emergence speed index, the effects of $F$. verticillioides on the initial development of plants of maize for all variables considered were inversely proportional to the initial inoculum intensity (potential) in the seeds.

\section{DISCUSSION}

The seed lot used in this study exhibited initially a high incidence of $F$. verticillioides and a high percentage of germination in the laboratory. To the Brazilian quality standards that seed lot can be commercialized for planting by growers. For that fungus no health standard has been settled in the certification programs and then no restriction exists about the occurrence of $F$. verticillioides in seed lots. In general, a high proportion of seed lots in Brazil presents variable levels of such fungal species. Under normal weather conditions, crop damage caused by that organism is hardly observed, neither on seed germination nor on the developing crop in the field. However, under stress conditions, in which high and prolonged relative humidity occur in some seasons damages caused by that species can be expressive, as part of a complex of other organisms causing seed deterioration (Williams et al., 2006; Wilke et al., 2007). Information on the single effects of $F$. verticillioides on seed performance and on the crop is hardly found in literature, except in cases mycotoxins are concerned (Williams et al., 2006).

From these results, it becomes clear that the presence of $F$. verticillioides in seed lots of maize may affect the performance of the emerged plants at variable intensity depending on the proportion of infected seeds with high inoculum potential. The highest inoculum potential in seeds, the most severe are the effects of the fungus on the development of the seeds and seedlings/plants.

In this work the osmo-priming technique used to screen seeds with different inoculum potentials of $F$. verticillioides proved to be useful and reliable as it has been demonstrated for other pathosystems (Machado et al ,2012) . It is worth to register that other techniques, as discussed by Machado and Carvalho (1975), Colhoun (1983), Cunfer (1983), Machado et al. $(2002,2012)$ in studies focused on the relationship between seed infection and disease development in the field, do not take into consideration the position and inoculum potentials of the pathogens in seeds. They consider only the levels of incidence (percentage) by taking different seed lots. In that case, several sources of variation, such as fungal races, origin of the lot, genetic nature of the host, may lead to different interpretation of the results. In addition, the inoculation of seeds by the soaking process, in which seeds are imbibed in conidial suspensions or by dry mixing seeds with inoculum, deals with the contamination process rather than infection (Machado and Langerak, 1993; Silva et al., 1999; Salustiano et al., 2005; Yates et al., 2005; Williams et al., 2006). It has been also demonstrated that seeds of some species submitted to soaking treatment may be physically injured.

The results of this work provide therefore an overview of the risk run by farmers on using maize seed lots with high proportion of seeds with high inoculum potential of Fusarium verticillioides. Under stress conditions that fungus may cause both quantitative and qualitative losses at large scale.

\section{ACKNOWLEDGEMENTS}

The authors express their thanks to Conselho Nacional de Desenvolvimento Científico e Tecnológico - CNPq and Fundação de Amparo à Pesquisa do Estado de Minas Gerais - FAPEMIG for the support in the development of this work and to Prof. Richard D. Berger (in memorian) of the University of Florida-USA for reviewing part of this manuscript.

\section{REFERENCES}

Carvalho JCB (1999) Uso da restrição hídrica na inoculação de Colletotrichum lindemuthianum em sementes de feijoeiro (Phaseolus vulgaris L.). M.Sc. Dissertation, Universidade Federal de Lavras. Lavras MG.

Colhoun J (1983) Measurement of inoculum per seed and its relation to disease expression. Seed Science and Technology 11:665-671.

Cunfer BM (1983) Epidemiology and control of seed-borne Septoria nodorum on wheat. Seed Science and Technology 11:707-718.

Dall'Asta C, Falavigna C, Galaverna G, Battilani P (2012) Role of maize hybrids and their chemical composition in Fusarium infection and fumonisin production. Journal of Agriculture and Food Chemistry 60:3800-3808.

De Leon C (1984) Enfermedades del maíz - una guía para su identificación en el campo. Centro Internacional de Mejoramiento de Maíz y Trigo (CIMMYT). $3^{\text {rd }}$ Ed. El Batán, Texcoco, Edo. de México. 114.

Fernandes FT, Oliveira E (2000) Principais doenças na cultura do milho. Embrapa Sete Lagoas Circular Técnica 26.

International Seed Testing Association (1996) International rules for seed testing. Seed Science and Technology 24(Suppl.):335.

Lazzari FA (1993) Umidade, fungos e micotoxinas na qualidade de sementes, grãos e rações. Curitiba PR. Edição do Autor. ISBN 85-900068-1-6.

Machado JC, Carvalho MG (1975) Comportamento de cultivares de soja (Glycine max) diante de isolamentos de 
Colletotrichum truncatum (Schw.) Andrus \& Moore e transmissão do patógeno pelas sementes em função da época de infecção da planta. Experientiae 19:120-148.

Machado JC, Langerak CJ (1993) Improvement of blotter method to detect economically important fungi associated with seeds of cotton. Proceedings of the International Seed Testing Association $1: 48-58$.

Machado JC (2000) Patologia de Sementes: fundamentos e aplicações. Brasília DF. MEC/ESAL/FAEPE.

Machado JC, Langerak CJ, Jaccoud-Filho DS (2002) Seed-borne fungi: A contribution to routine seed health analysis. $1^{\text {st }}$ Ed. Zürich Switzerland. International Seed Testing Association.

Machado JC, Barrocas EN, Costa MLN, Guimarães RM, Machado CF (2012) Uso da técnica de restrição hídrica ou "condicionamento osmótico" em patologia de sementes. Revisão Anual de Patologia de Plantas 20:37-63.

Maguire JD (1962) Speed of germination aid in selection and evaluation for seedling emergence and vigor. Crop Science 2:176177.

Michel BE, Radcliffe D (1995) A computer-program relating solute potential to solution composition for 5 solutes. Agronomy Journal 87:126-130.

Neergaard P(1979) Seed Pathology, vol.1. London UK. Macmillan Press.

Rheeder JP, Marasas WFO, Vismer HF (2002) Production of fumonisin analogs by Fusarium species. Applied Envirommental Microbiology 68:2101-2105.
Richardson MJ (1979) An annotated list of seed-borne diseases, $3^{\text {th }}$ Ed. Kew England. Commonwealth Mycological Institute.

Salustiano ME, Machado JC, Pittis JE (2005) Patogenicidade de Alternaria helianthi (Hansf.) e Alternaria zinniae (Pape) ao girassol a partir de sementes. Revista Brasileira de Sementes 27:138-143

Silva EAA, Von Pinho EVR, Vieira MGGC, Machado JC, Carvalho ML (1999) Padrões eletroforéticos de proteínas tipo zeína em sementes de milho inoculadas com Aspergillus flavus, Fusarium moniliforme e Penicillium spp. Revista Brasileira de Sementes 21:258-263.

Singh K, Frisvad JC, Thrane U, Mathur SB (1991) An illustrated manual on identification of some seed-borne Aspergilli, Fusaria, Penicillia and their mycotoxins. Hellerup Denmark. Danish Government Institute for Developing Countries.

Wilke AL, Bronson CR, Tomas A, Munkvold GP (2007) Seed transmission of Fusarium verticillioides in maize plants grown under three different temperature regimes. Plant Disease 91:11091115.

Williams LD, Glenn AE, Bacon CW, Smith MA, Riley RT (2006) Fumonisin production and bioavailability to maize seedlings grown from seeds inoculated with Fusarium verticillioides and grown in natural soils. Journal of Agricultural and Food Chemistry 54:5694-5700.

Yates IE, Widstrom NW, Bacon CW, Glenn A, Hinton DM, Sparks D, Jaworski AJ (2005) Field performance of maize grown from Fusarium verticillioides-inoculated seed. Mycopathologia 159:6573.

TP $\overline{\text { 2012-0093 - Received } 26 \text { September } 2012 \text { - Accepted } 3 \text { January } 2013}$

Section Editor: Murillo Lobo Junior 